\author{
Jędrzej Gadziński \\ $\mathrm{dr}$ \\ Instytut Geografii Społeczno-Ekonomicznej \\ i Gospodarki Przestrzennej, \\ Uniwersytet im. Adama Mickiewicza w Poznaniu \\ jedgad@amu.edu.pl

\section{Radosław Bul} \\ dr \\ Instytut Geografii Społeczno-Ekonomicznej \\ i Gospodarki Przestrzennej, \\ Uniwersytet im. Adama Mickiewicza w Poznaniu \\ bul@amu.edu.pl
}

DOI: 10.35117/A_ENG_17_04_01

\title{
Planning new public transport line based on accessibility criteria
}

\begin{abstract}
The changing role of public transport in Polish cities and contemporary urbanisation processes can be recognized as the most important reasons for the rapid development of bus and tram networks in last years. It seems that a key factor which could attract new passengers is the improvement in the level of accessibility. Therefore, the main aim of this article is to present a methodology based on the accessibility measures, which could help in the planning of the public transport networks in urban areas. Świerczewo district in the southern part of Poznań was adopted as an research area. Conducted analyses showed that the proposed method could help in the selection of an optimal bus line and stops location. The conclusion is that such an objective approach should be taken into account when the decisions on the future of public transport networks will be made.
\end{abstract}

Keywords: Accessibility; Public transport; GIS

\section{Introduction}

Lately in Poland, a gradual change in perception of the role of public transport in large urban areas has been observed. It ceases to appear only as a public service of a social character. More attention is paid to its positive effects on urbanized space. The emphasis is on the role of public transport in the revitalization of individual districts [5],[18],[34]. Awareness of the potential benefits of the priorities for trams and buses introdution has been improving among the city masters and office workers (while introducing some restrictions on individual car transport). Among these benefits are, inter alia, "recovery" of public space [29], decreases in pollutant emissions and noise [13],[16], improvement in safety [23], elimination of restrictions on pedestrian traffic [32].

As a result, many cities are increasingly determined to promote and develop public transport. This is to encourage more people to use buses, trams or urban railways in their daily commute. Ideas for particular solutions that would increase the role of public transport are many. However, it seems that one of the basic conditions for increasing its popularity is the thoughtful development of the network of connections that will lead to improved accessibility [24]. This is particularly important in the context of the progressive urban sprawl [7]. In this context, it is worth considering the principles of network optimization and how it can be used to determine the future direction of public transport. It seems that in the first place, the 
postulates of local communities have been followed (which seems to be correct), although in many cases the "trial and error method" has been used. There are no objective tools that could be an important complementary element used in the decision-making process.

The main aim of the article is to show the possibility of using accessibility measures as an auxiliary element in planning the development of public transport networks. The analysis concerns the evaluation of the new public transport route in the three proposed options. The level of accessibility of bus stops was considered as the main criterion. All analyzes were carried out for the area of the Świerczewo estate located in the southern part of Poznan (the areas between Świerczew and the city center - parts of the Górczyn and Św. Łazarz.

\section{Accessibility and methods of measurement}

Accessibility is a very common term for transport activities (transport accessibility) but also for various other activities (accessibility of jobs, schools, hospitals, cinemas, etc.). In many strategic publications at local or regional level, accessibility is one of the main development objectives (e.g. [27],[30]). There are also numerous scientific and expert studies where the authors examine the accessibility of individual cities [35], regions [11], category of objects [16] or services [12][31]. At the same time, however, it is still not an unambiguous term and often used in inappropriate contexts (e.g. often confused with mobility - cf. [4]).

The most common definitions identify accessibility with some ease in achieving a given location [3][19][20], with the possibility of interaction [10][14] or the possibility of participation in certain activities [2]. This understanding of accessibility makes its level most often determined by the distance (physical, temporal or economic) between two points in expanse. However, it is worth noting that ease of access to the place determines not only the distance, but also other elements such as the way of management of the space in which the displacement is carried out, the personal characteristics of the traveler, the specificity of the displacement and the destination, and even the current weather. The accessibility level of selected locations may be different for different social groups, means of transport, times of the day, etc. This approach makes it difficult to measure its level significantly. As a result, with some sort of analysis, some simplifications are most often applied.

In the case of public transport, the route of the line (metro, city rail, tram, bus) is most often taken into account in the accessibility studies, omitting the individual characteristics of passengers and other difficult-to-measure elements. The picture of the public transport accessibility in a given city, region or country is always a certain simplification of the actual situation. It is important, however, to include as many aspects of accessibility as possible in the study, so that the resulting image is as close as possible to the actual situation.

It is worth noting that accessibility of public transport can be considered in two scenarios [6][22]. On the one hand it analyzes the possibility of reaching the stops or means of transport, and on the other hand the ease of getting to the final destination (e.g. city center accessibility when using public transport). In the first case only the route to the stop is taken into account. In turn, in the second approach, the level of accessibility of the destination consists, among others accessibility of stops / means of transport, characteristics of the displacement (including necessary transfers), accessibility of the destination after leaving the means of transport.

For a full picture of availability (in the region, city, etc.) there are used different methods (see [28]). It seems that the most commonly used types of analyzes are ecodesysts or isochrones, which are designated around public transport stops in the form of circles of a certain radius (cf. [26]). The actual way of reaching the stops is not taken into consideration all barriers (e.g. fences, waterways, railway lines) and road lengths resulting from the shape of the road network are ignored. As a result, the results may be somewhat falsified. One solution 
to this problem is the use of a calculator, which takes into account the average length of the road in the analyzed area. It can vary considerably in areas with different characteristics, which results from the type of development and distribution of the road network. Tests carried out in different centers show that the coefficient of elongation is usually from 1.15 to 1.35 (see [6][21][23]). This means that the actual route to the stop is on average $15 \%$ to $35 \%$ longer than the distance measured in a straight line (Figure 1). However, it is still some kind of simplification of the actual situation (for individual locations within a single city the indicator may vary by several dozen percent). It appears, however, that its use may be justified, for example, in studies conducted at regional level or in large urban centers and agglomerations (among others due to the considerable complexity of the road network).

Much less frequently, in surveys of accessibility levels, measurements are made on the basis of actual access routes. This is due to the complexity of such analyzes, and in the past it was also related to the lack of appropriate source data and software. One of the first such models (using GIS capabilities) was proposed by Yigitcanlar and others [37]. In an analysis conducted for the Gold Coast area (Australia), the accessibility of stops was determined on the basis of a real road network and paths. As a result, the designated ranges were in the form of corridors running along these roads (Fig. 1). It seems that this solution represents the best level of actual accessibility and especially in large scale projects (e.g. for neighborhoods, settlements, small towns). It is therefore worth considering the use of this type of accessibility analysis when planning specific solutions for the development of public transport networks at local level.
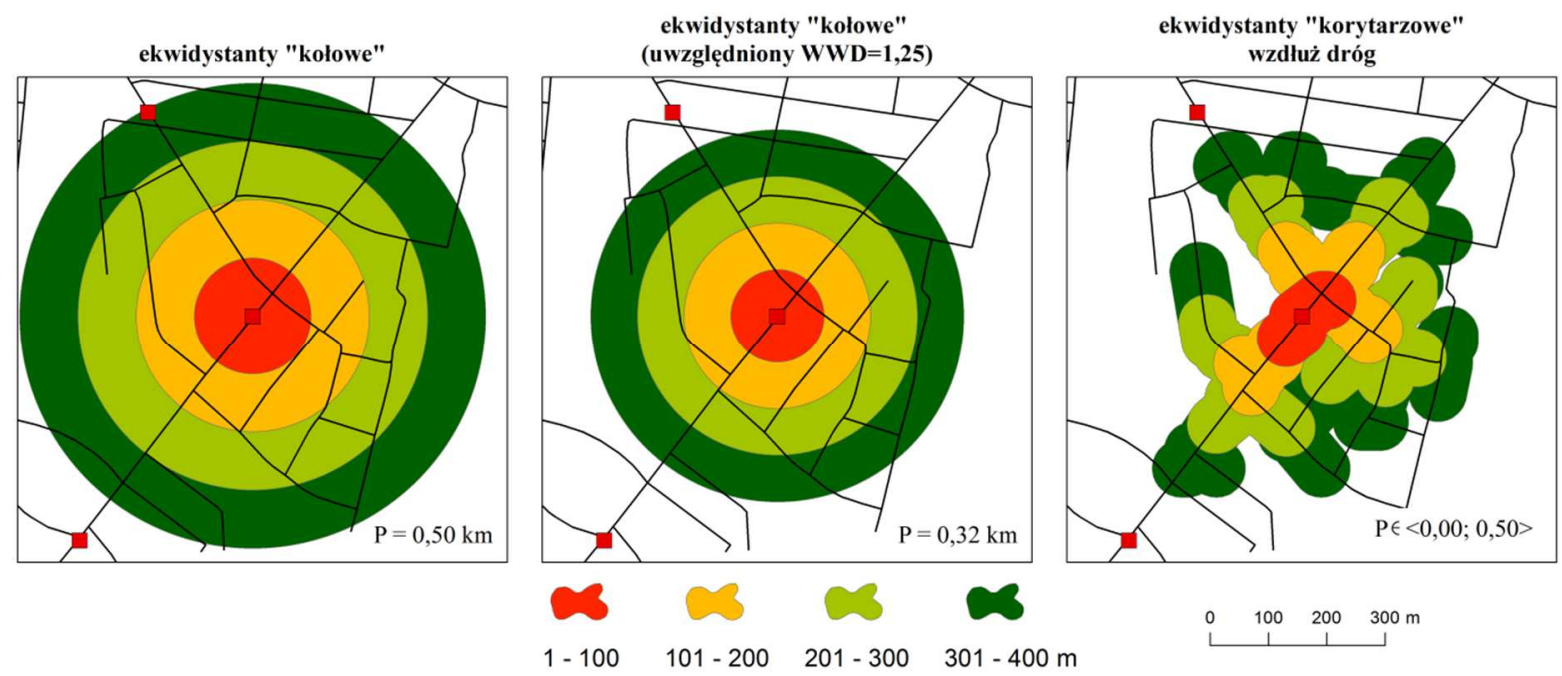

1. Comparison of the range of stops determined by different methods. Source: own work.

\section{Methodology and research area}

The study decided to use "corridor" scales to analyze the level of accessibility of public transport within one of the peripheral parts of Poznan. The present form of the network has been verified (Figure 2), as well as three proposed variants of changes (consisting in the introduction of a new bus line linking the analysis area to the center of Poznań). The different possibilities of the route are presented in Figure 3, and their characteristics in Table 1. 
Tab.1. Characteristics of public transport networks in the analyzed area (with the proposed changes). Source: own work.

\begin{tabular}{|c|c|c|c|c|c|c|}
\hline \multirow{2}{*}{ Bus network } & \multirow{2}{*}{ 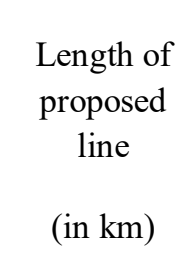 } & \multirow{2}{*}{$\begin{array}{l}\text { Estimated } \\
\text { travel time } \\
\text { (one way, } \\
\text { min.) }\end{array}$} & \multicolumn{2}{|c|}{ Number of stops } & \multicolumn{2}{|c|}{$\begin{array}{l}\text { The area range of } 400 \text { meters } \\
\text { (in } \mathrm{km} 2 \text { ) }\end{array}$} \\
\hline & & & $\begin{array}{l}\text { on the } \\
\text { proposed line }\end{array}$ & $\begin{array}{l}\text { throughout } \\
\text { the analyzed } \\
\text { area }\end{array}$ & $\begin{array}{l}\text { around the } \\
\text { proposed line }\end{array}$ & $\begin{array}{l}\text { for the whole } \\
\text { analyzed area }\end{array}$ \\
\hline no change & - & - & - & 34 & - & 5,61 \\
\hline option 1 & 12,82 & 23 & 15 & 37 & 2,32 & 5,84 \\
\hline option 2 & 15,85 & 26 & 16 & 40 & 2,80 & 5,99 \\
\hline option 3 & 13,40 & 26 & 15 & 40 & 2,49 & 6,12 \\
\hline
\end{tabular}

The areas with good accessibility in each variant were those that were distant from the stops of up to 400 meters (see [1][25][33][38]) and were directly on the roads (as well as other paths, routes, routes available for pedestrians). Source data (road network, buildings) was obtained from the database of topographic objects and was supplemented with information from the OpenStreetMap website.

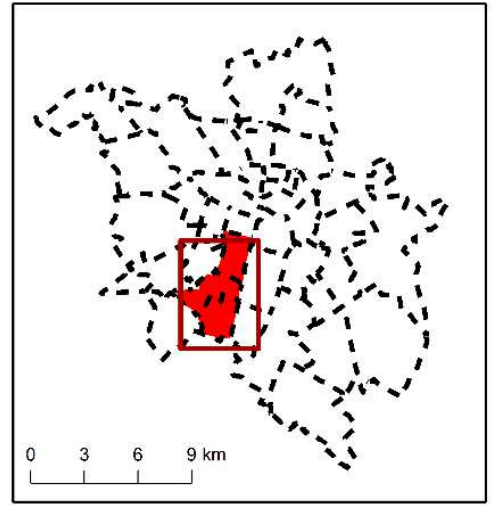

- przystanki

drogi

- linie tramwajowe

- linie autobusowe

- - granice osiedli w Poznaniu

analizowane osiedla

$\overline{1, \bar{\prime}}$ granica obszaru analiz

zabudowa mieszkaniowa
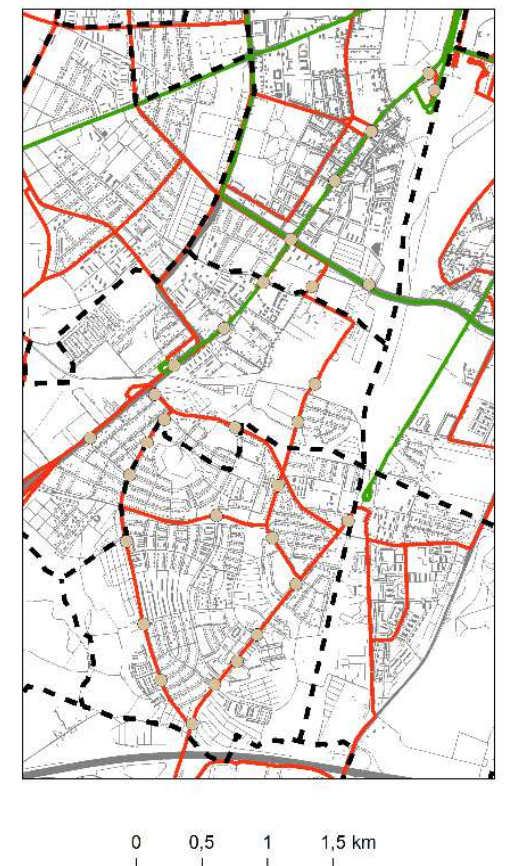

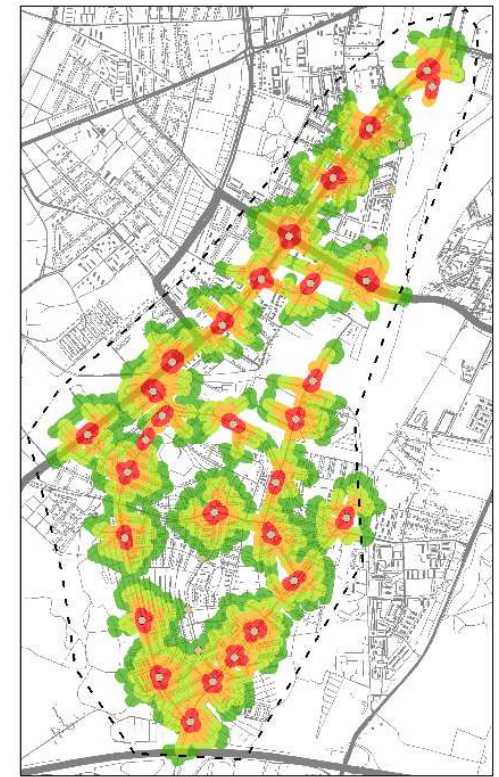

Droga dojścia do przystanku (w metrach):

$\sim 1-100 \quad 201-300$ C5 $101-200 \backsim 301-400$

2. The organization and the accessibility level of public transport in the analyzed area. Source: own work 
In analyzes, in the first place for each variant were designated areas with access to public transport. Also, there were defined some areas where, thanks to the new line, accessibility would be increased. The second step was to estimate the number of buildings and the number of inhabitants for each designated area. On this basis, the proposed bus line and its course were assessed. This made it possible to identify objectively the best variants.

The study area was chosen in the southern part of Poznań, covering mainly the Świerczewo estate. The analysis also included areas between Świerczewo and the center of Poznan (to show the course of the entire planned bus route). The main argument that influenced the selection of the research area was that the area of Świerczewo was characterized by a relatively low level of public transport accessibility (see Figure 2) and there are several possibilities for the future development of the bus network. In 2015 (according to GEOPOZ) the area of Świerczewo was inhabited by 14,230 people. As a result, it was the largest single family housing estate in Poznań. Świerczewo is located directly at the southern border of the city (in common with the Lubon municipality), in close proximity to the A2 motorway and only about $5 \mathrm{~km}$ from the center of Poznan. Despite this relatively favorable location, the level of public transport services in the housing estate appears to be insufficient. As a result, as shown by the results of studies carried out for the Poznan Agglomeration Transport Plan [27], the share of public transport in displacement within the estate is only $31.9 \%$ (41.0\% in Poznań). In turn, the percentage of motorized households in Świerczewo is $69.4 \%$, while in Poznań it is only $52.9 \%$.

The area of the estate is served by six bus lines. However, one must admit that the frequencies of the courses vary widely, and the three lines pass the edge of the estate as "by the way" as their primary task is to service neighboring communes - Luboń and Komorniki). It is noteworthy that the buses are mainly on roads located on the outskirts of Świerczewo and as a result the central part of the estate is not served by public transport (Figure 2). At the same time none of the existing lines does not provide a direct connection of the settlement to the center of Poznan - they bring passengers to the tram loop located in the southern part of Poznan (Górczyn and Dębiec node). In this context, it is worth asking about the possibility of improving this situation and possible directions of development of the bus network in this area.

\section{Expected change in the accessibilty of stops chain}

By determining the range of public transport stops located in the area of analysis and along the proposed new bus route, it was possible to analyze the validity of each of the three considered options. The assessment was based not only on the areas of good accessibility but also on the location of the buildings and the population in the research area. The obtained results are presented in tab. 2 and Figures 3 and 4.

Tab.2.: Effects of the introduction of a new bus line. Source: own work.

\begin{tabular}{|l|l|l|l|l|}
\hline & $\begin{array}{l}\text { number } \\
\text { residential of } \\
\text { buildings within } \\
\text { the proposed line }\end{array}$ & $\begin{array}{l}\text { number of } \\
\text { inhabitants within } \\
\text { the proposed line }\end{array}$ & $\begin{array}{l}\text { Number of } \\
\text { buildings that have } \\
\text { access to TP }\end{array}$ & $\begin{array}{l}\text { Number } \\
\text { residents who have } \\
\text { access to TP }\end{array}$ \\
\hline option 1 & 1439 & 8591 & 104 & 1900 \\
\hline
\end{tabular}




\begin{tabular}{|l|l|l|l|l|}
\hline option 2 & 2422 & 11525 & 363 & 2735 \\
\hline option 3 & 2049 & 10303 & 510 & 3141 \\
\hline
\end{tabular}

In each of the proposed new bus routes, the level of public transport accessibility would improve. However, the potential benefits vary widely depending on the course of the routes. Availability of public transport will generally not improve if a new bus line is introduced in Option 1. (Figure 3). The inhabitants of Świerczewo will gain a direct connection to the city center, but their routes to the terminals will not be shortened. Accessibility of public transport will improve only in areas in close proximity to the train station (in the area of Street Kolejowa). The bus line in this variant will provide a direct connection to the center for residents with 1.4 thousand. (approximately 8.5 thousand people). However, most of these buildings are already in close proximity to other bus lines. As a result, access to public transport will benefit from this connection (and new stops) by an additional 1.9 thousand "new" inhabitants of just over 100 buildings (the area of the railway). As a result, the potential impact of the proposed line on improving accessibility appears to be relatively small.
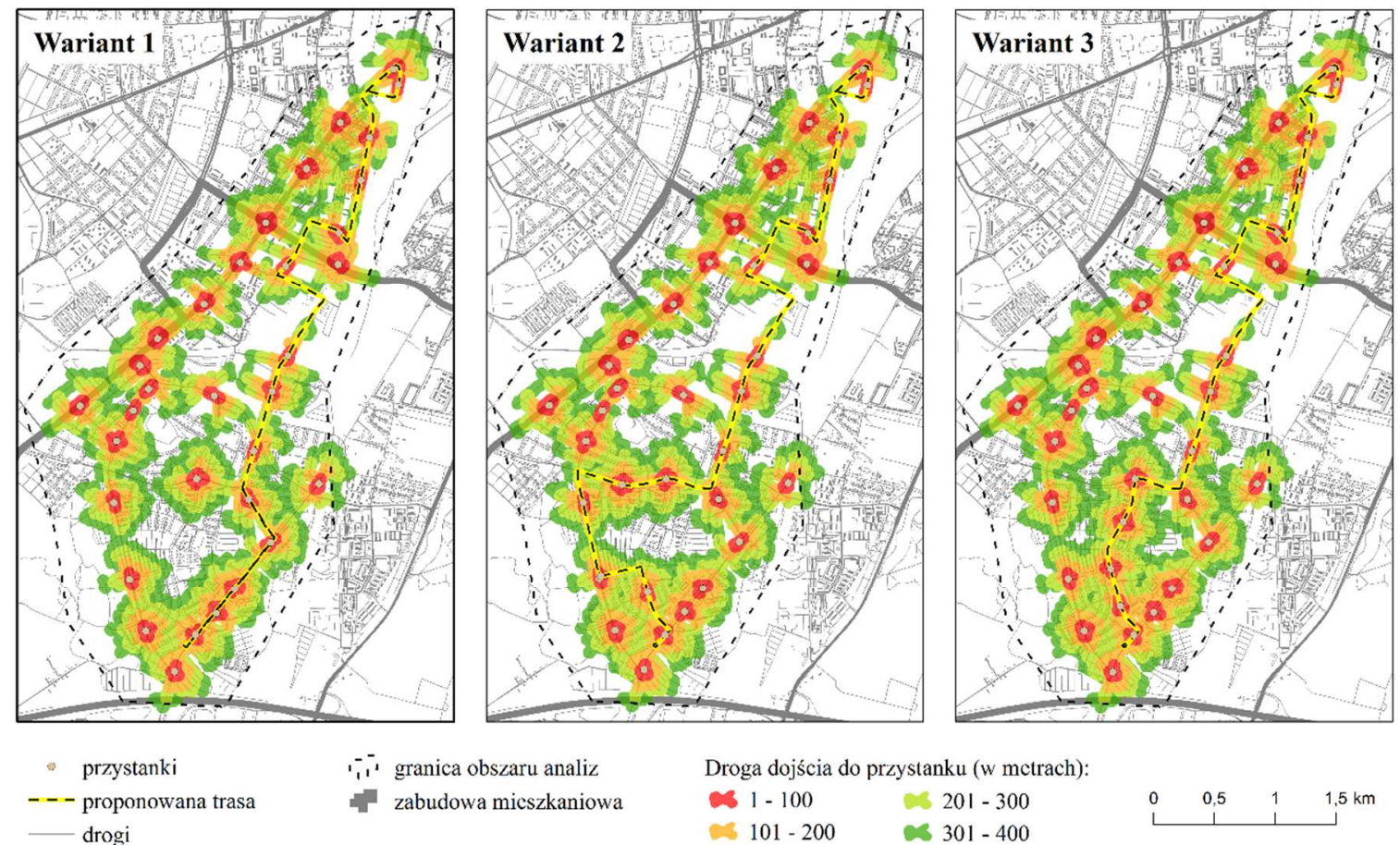

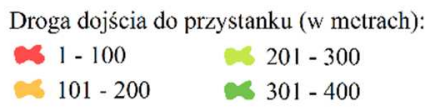

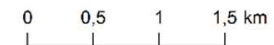

3. Accessibility of stops in the analyzed area after the introduction of an additional bus line. Source: own work.

The new bus line in option 2 would contribute to a significant improvement in transport accessibility, particularly in the south-central and partly in the central part of Świerczewo (Figures 3 and 4). This would be possible thanks to the creation of new stops on the street running through the central part of the estate. At the same time, however, this proposal does not solve the problem of limited availability in the north-central part of Świerczewo. In the proposed variant of a direct connection to the center have obtained more than 11.5 thousand inhabitants (living in 2.4 thousand buildings). 24\% (2.7 thousand people) 
of them currently have difficulty accessing the stops and thanks to the new line it would be much easier to use public transport.

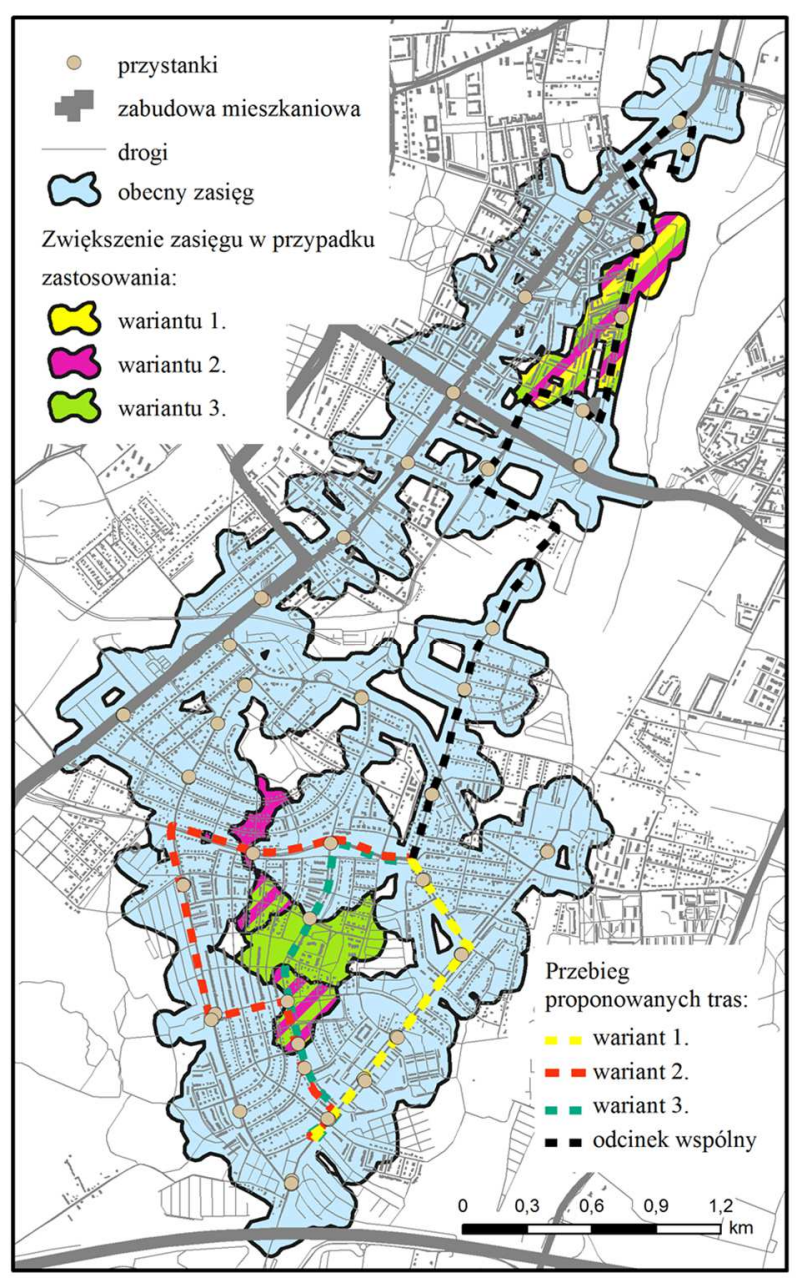

4. Change of public transport accessibility depending on the chosen variant of the new bus route. Source: own work.

It seems that the most beneficial impact on improving the accessibility of public transport could be proposed bus line option 3 (Fig. 3). Due to the relatively long distance between the central part of the settlement and the new stops there, many people living in areas with restricted access to public transport would be able to easily take bus journeys. Good access to the proposed new bus line would be about 10 thousand people (living in about 2 thousand buildings), so that they could go direct to the central part of Poznan. At the same time, $30 \%$ of these people (3.1 thousand inhabitants) do not currently have sufficient access to public transport stops. As a result, the new line could encourage them to use public transport more often in Poznań.

\section{Summary}

In conclusion, from the presented proposals the most favorable (from the point of view of improving the availability of public transport stops possibilities) seems to be option 3 . With 
the introduction of a new line of such a course, a significant number of new residents would be able to use public transport on daily trips. It is worth emphasizing that the improvement of stops availability seems to be the key to attracting new passengers to public transport (and indirectly also the better functioning of the whole transport system). This is particularly important in the light of current transport policies that point to public transport as a priority for urban mobility. As indicated by many research centers, a short and trouble-free way to the stops is a key factor affecting the popularity of railways, trams and buses [15][17]. As a result, accessibility levels can substantially affect spatial behavior of the population. For example, in a previous study conducted in Poznań [9] it was shown people living directly at tram stops are more likely to use public transport than residents of outlying settlements.

The analysis proposed in the article can be successfully applied in practical activities related to the planning of the development of public transport networks. Through such studies, people responsible for these issues (municipal offices, municipalities, transport boards and transport companies) would benefit from instruments showing the potential benefits that might result from introducing new connections. Further, the proposed analyzes can also be extended to cost analyzes that generate individual solutions. This would make it possible to assess their effectiveness (the relation of costs incurred to the achieved effects). It should also investigate other potential benefits of the new connection, such as increasing range of travel destinations, improved service frequency and shortening the travel time to key destinations. These elements can significantly influence the growing popularity of public transport and also be a significant argument for the development of the network in certain directions. At the same time, it should be emphasized that such studies should be regarded as a complement to the decision-making process. It is also worthwhile to listen to the voices of local communities (e.g. council settlements) and to analyze the technical aspects.

\section{Source materials}

[1] Accessible bus stop guidance, 2006. Transport for London, Londyn.

[2] Burns L., 1979. Transportation, temporal and spatial components of accessibility. Lexington Boks, Londyn.

[3] Dalvi M., Martin K., 1976. The measurement of accessibility: some preliminary results. Transportation, 5, s. 17-42.

[4] El-Geneidy A., Levinson D., 2006. Access to destinations: Development of accessibility measures. Minnesota Department of Transportation, Research Services Section, Minnesota.

[5] Evans G., Shaw S., 2001. Urban leisure and transport: regeneration effects. Journal of Retail \& Leisure Property, 1(4), s. 350-372.

[6] Gadziński J., 2010. Ocena dostępności komunikacyjnej przestrzeni miejskiej na przykładzie Poznania. Biuletyn Rozwój Regionalny i Polityka Regionalna, 13. Bogucki Wydawnictwo Naukowe, Poznań.

[7] Gadziński J., 2012. Lokalizacja przystanków a konkurencyjność transportu publicznego w aglomeracji poznańskiej. W: Szymczak M. (red.), Transport publiczny w aglomeracji poznańskiej - propozycje usprawnień. Biblioteka Aglomeracyjna 9, Bogucki Wydawnictwo Naukowe, Poznań, s. 69-90.

[8] Gadziński J., Beim M., 2009. Dostępność przestrzenna lokalnego transportu publicznego w Poznaniu. Transport Miejski i Regionalny, 5, s. 10-16.

[9] Gadziński J., Radzimski A., 2015, The first rapid tramline in Poland: How has it affected travel behaviours, housing choices and satisfaction, and apartment prices? Journal of Transport Geography, http://dx.doi.org/10.1016/j.jtrangeo.2015.11.001. 
[10] Geurs K., van Wee B., 2004. Accessibility evaluation of land-use and transport strategies: review and research directions. Journal of Transport Geography, 12, s. 127-140.

[11] Grzelakowski A., 2003. Dostępność transportowa regionów jako element ich potencjału rozwojowego. Przegląd Komunikacyjny, 42, s. 11-16.

[12] Guzik R., 2003. Przestrzenna dostępność szkolnictwa ponadpodstawowego. Instytut Geografii i Gospodarki Przestrzennej Uniwersytetu Jagiellońskiego, Kraków.

[13] Gwilliam K. M., Kojima M., Johnson T., 2004. Reducing air pollution from urban transport. World Bank, Waszyngton.

[14] Hansen W., 1959. How accessibility shapes land use. Journal of American Institute of Planners, 25, s. 73-76.

[15] Hass-Klau C., Crampton G., 2002. Future of Urban Transport, Learning from Success and Weaknesses: Light Rail. Environmental and Transport Planning, Brighton.

[16] Komornicki T., Śleszyński P., 2009. Studia nad lokalizacją regionalnych portów lotniczych na Mazowszu. IGiPZ PAN, Warszawa.

[17] Lane B.W., 2008. Significant characteristics of the urban rail renaissance in the United States: A discriminant analysis. Transportation Research Part A: Policy and Practice, 42(2), s. 279-295.

[18] Lawless P., Gore T., 1999. Urban regeneration and transport investment: a case study of Sheffield 1992-96. Urban Studies, 36(3), s. 527-545.

[19] Litman T., 2008. Evaluating accessibility for transportation planning. Victoria Transport Policy Institute, Victoria.

[20] Liu S., Zhu X., 2004. An integrated GIS approach to accessibility analysis. Transactions in GIS, 8, s. 45-62.

[21] Loose W., 2001. Flächennutzungsplan 2010 Freiburg - Stellungnahme zu den verkehrlichen Auswirkungen. Öko-Institut e.V., Freiburg.

[22] Mavoa S., Witten K., McCreanor T., O'Sullivan D., 2012. GIS based destination accessibility via public transit and walking in Aucland, New Zealand. Journal of Transport Geography, 20, s. 15-22.

[23] Mohan D., Tiwari G., 1999. Sustainable transport systems: linkages between environmental issues, public transport, non-motorised transport and safety. Economic and Political Weekly, s. 1589-1596.

[24] Moniruzzaman M., Páez A., 2012. Accessibility to transit, by transit, and mode share: application of a logistic model with spatial filters. Journal of Transport Geography, 24, s. 198205.

[25] Murray A.T., Davis R., Stimson R.J., Ferreira L., 1998. Public Transportation Access. Transportation Research Part D: Transport and Environment, 3 (5), s. 319-328.

[26] O'Sullivan D., Morrison A., Shearer J., 2000. Using desktop GIS for the investigation of accessibility by public transport: an isochrone approach. International Journal of Geographical Information Science, 14(1), s. 85-104.

[27] PTAP, 2014. Plan Transportowy Aglomeracji Poznańskiej na lata 2014-2020, Urząd Miasta w Poznaniu, Starostwo Powiatowe w Poznaniu, Poznań.

[28] Rosik P., 2012. Dostępność lądowa przestrzeni Polski w wymiarze europejskim. Prace Geograficzne, 223. IGiPZ PAN, Warszawa.

[29] Sheller M., Urry J., 2000. The city and the car. International journal of urban and regional research, 24(4), s. 737-757.

[30] Strategia Rozwoju Transportu do 2020 roku (z perspektywą do 2030 roku), 2013. Ministerstwo Transportu, Budownictwa i Gospodarki Morskiej, Warszawa.

[31] Taylor Z., 1999. Przestrzenna dostępność miejsc zatrudnienia, kształcenia i usług a codzienna ruchliwość ludności wiejskiej. IGiPZ PAN, Warszawa. 
[32] Topp, H., Pharoah, T., 1994. Car-free city centres. Transportation, 21(3), s. 231-247. [33] Tyler N., 2002. Accessibility and the Bus System: From Concepts to Practice. Thomas Telford Ltd, Londyn.

[34] Wesołowski J., 2008, Miasto w ruchu. Przewodnik po dobrych praktykach w organizowaniu transportu miejskiego. Instytut Spraw Obywatelskich, Łódź.

[35] Wiśniewski S., 2014. Dostępność transportowa Uniejowa-ujęcie regionalne. Biuletyn Uniejowski, 3, s. 67-84.

[36] Woodcock J., Edwards P., Tonne C., Armstrong B. G., Ashiru O., Banister D., Franco O.H., 2009. Public health benefits of strategies to reduce greenhouse-gas emissions: urban land transport. The Lancet, 374(9705), s. 1930-1943.

[37] Yigitcanlar T., Sipe N., Evans R., Pitot M., 2007. A GIS-based land use and public transport accessibility indexing model. Australian Planner 44, 3, s. 30-37.

[38] Zhao F., Chow L., Li M., Ubaka I., Gan A., 2003. Forecasting transit walk accessibility: Regression model alternative to buffer. Transportation Research Record, 1835,s. 34-41. 